\title{
THE EFFECTS OF TESTOSTERONE, DIHYDROTESTOSTERONE AND OESTRADIOL ON THE COMB AND OVIDUCT OF THE FEMALE DOMESTIC FOWL*
}

\author{
F. J. ZELLER \\ Zoology Department, Indiana University, \\ Bloomington, Indiana 47401, U.S.A.
}

(Received 23rd October 1972)

The possibility that dihydrotestosterone (DHT) may be the intracellular active form of testosterone (Bruchovsky \& Wilson, 1968) has led to many investigations of their effects on reproductive structures in both sexes (Gloyna \& Wilson, 1969; Gonzalez-Diddi, Komisaruk \& Beyer, 1972). In this communication, the synergistic effects of testosterone propionate (TP) and DHT on oestradiol stimulation of the immature chick oviduct are compared.

Single-comb White Leghorn fowl, 12 to 15 days old at the start of the experiments, were used. Birds were the same age in any one experiment. The steroids (TP, DHT and oestradiol benzoate or dipropionate) were suspended in sesame oil and injected subcutaneously for 7 days. All animals, including the controls, received $0.1 \mathrm{ml}$ sesame oil/day. At autopsy, the combs and oviducts were quickly removed and weighed to the nearest $\mathrm{mg}$. Comb data are presented to give an indication of the androgen activity.

Table 1. The effects of oestradiol benzoate, testosterone propionate or dihydrotestosterone on comb and oviduct weights of female fowl treated for 7 days

\begin{tabular}{l|c|c|c}
\hline \multicolumn{1}{c|}{ Dose/day } & $\begin{array}{c}\text { No. of } \\
\text { fowl }\end{array}$ & $\begin{array}{c}\text { Comb wt } \\
(m g \pm S . D .)\end{array}$ & $\begin{array}{c}\text { Oviduct wt } \\
(m g \pm S . D .)\end{array}$ \\
\hline Control & 9 & $51 \pm 12$ & $24 \pm 7$ \\
$10 \mu \mathrm{g} \mathrm{OB}$ & 9 & $44 \pm 15$ & $102 \pm 23$ \\
$10 \mu \mathrm{g} \mathrm{OB}+200 \mu \mathrm{g} \mathrm{TP}$ & 10 & $434 \pm 85$ & $295 \pm 56^{* *}$ \\
$10 \mu \mathrm{g} \mathrm{OB}+100 \mu \mathrm{g}$ DHT & 10 & $159 \pm 59$ & $191 \pm 49$ \\
$10 \mu \mathrm{g} \mathrm{OB}+200 \mu \mathrm{g}$ DHT & 10 & $218 \pm 54$ & $213 \pm 46$ \\
$10 \mu \mathrm{g} \mathrm{OB}+400 \mu \mathrm{g}$ DHT & 9 & $278 \pm 64$ & $239 \pm 38$ \\
$10 \mu \mathrm{g} \mathrm{OB}+800 \mu \mathrm{g} \mathrm{DHT}$ & 8 & $300 \pm 60$ & $247 \pm 47$ \\
\hline
\end{tabular}

Age of fowl at autopsy $=22$ days. $\mathrm{OB}=$ oestradiol benzoate; $\mathrm{TP}=$ testosterone propionate; $\mathrm{DHT}=$ dihydrotestosterone.

** $P<0.01$ compared to all doses of $\mathrm{DHT}+\mathrm{OB}$.

In a series of experiments, it was noted that, when given alone, $50 \mu \mathrm{g}$ or $200 \mu \mathrm{g}$ of TP or DHT/day had no effect on oviduct weight. A daily $50-\mu \mathrm{g}$ dose

* Contribution No. 900 from the Zoology Department, Indiana University. 
of either TP or DHT had about the same synergistic effect when given with $10 \mu \mathrm{g}$ oestradiol. Table 1 contains data which allow a comparison to be made of the effects of higher doses of the androgens and it can be seen that $200 \mu \mathrm{g}$ TP had a greater synergistic effect with $10 \mu \mathrm{g}$ oestradiol benzoate than did 100 , 200,400 or even $800 \mu \mathrm{g}$ DHT. Similar results were obtained in other experiments using oestradiol dipropionate.

The results from these experiments indicate that $\mathrm{TP}$ has a greater synergistic effect with oestradiol than DHT on the oviduct of the immature fowl.

\section{REFERENCES}

BRuchovsky, N. \& WiLson, J. D. (1968) The conversion of testosterone to $5 \alpha$-androstan-17 $\beta$-ol-3-one by rat prostate in vivo and in vitro. 7. biol. Chem. 243, 2012.

Gloyna, R. E. \& Wirson, J. D. (1969) A comparative study of the conversion of testosterone to $17 \beta$-hydroxy- $5 \alpha$-androstan-3-one (dihydrotestosterone) by prostate and epididymis. 7 . clin. Endocr. Metab. 29, 970.

Gonzalez-Diddi, M., Komisaruk, B. \& Beyer, G. (1972) Differential effects of testosterone and dihydrotestosterone on the diverse uterine tissues of the ovariectomized rat. Endocrinology, 91, 1129 . 